\title{
Influence of the High-Affinity Growth Hormone (GH)-Binding Protein on Plasma Profiles of Free and Bound GH and on the Apparent Half-Life of GH

\author{
Modeling Analysis and Clinical Applications
}

\author{
Johannes D. Veldhuis, " Michael L. Johnson, ${ }^{*}$ Lindsay M. Faunt, ${ }^{\star}$ Moises Mercado, and Gerhard Baumann` \\ ${ }^{*}$ Division of Endocrinology and Metabolism, Departments of Internal Medicine and ${ }^{\ddagger}$ Pharmacology, University of Virginia Health \\ Sciences Center, and National Science Foundation Center for Biological Timing, Charlottesville, Virginia 22908; and ${ }^{\$}$ Center for \\ Endocrinology, Metabolism and Nutrition, Department of Medicine, Northwestern University Medical School, Chicago, Illinois 60611
}

\begin{abstract}
The discovery of a specific high-affinity growth hormone (GH) binding protein (GH-BP) in plasma adds complexity to the dynamics of GH secretion and clearance. Intuitive predictions are that such a protein would damp sharp oscillations in $\mathbf{G H}$ concentrations otherwise caused by bursts of GH secretion into the blood volume, prolong the apparent half-life of circulating GH, and contribute a reservoir function. To test these implicit considerations, we formulated an explicit mathematical model of pulsatile GH secretion and clearance in the presence or absence of a specific high-affinity GH-BP. Simulation experiments revealed that the pulsatile mode of physiological GH secretion creates a highly dynamic (nonequilibrium) system, in which the half-life of free $\mathbf{G H}$, its instantaneous secretion rate, and the GH-BP affinity and capacity all contribute to defining momentary levels of free, bound, and total GH; the percentage of GH bound to protein; and the percentage occupancy of GHBP. In contrast, the amount of free GH at equilibrium is specified only by the GH distribution volume and secretion rate and the half-life of free hormone. We conclude that the in vivo dynamics of GH secretion, trapping, and clearance from the circulation offer a variety of regulatory loci at which the time structure of free, bound, and total GH delivery to target tissues can be controlled physiologically. (J. Clin. Invest. 1993. 91:629641.) Key words: diabetes mellitus • growth hormone $\bullet$ Laron dwarfism • obesity
\end{abstract}

\section{Introduction}

Recently a high-affinity, specific, low-capacity growth hormone-binding protein (GH-BP) ${ }^{1}$ that circulates in blood has been characterized, purified, and cloned in humans and several animal species (1-7). This high-affinity GH-BP corresponds to the extracellular domain of the tissue growth hormone (GH) receptor (5-9), and contrasts with an incompletely character-

Address reprint requests to Dr. Johannes D. Veldhuis, Division of Endocrinology and Metabolism, Box 202, Department of Internal Medicine, University of Virginia Health Sciences Center, Charlottesville, VA 22908.

Received for publication 17 April 1992 and in revised form 4 September 1992.

1. Abbreviations used in this paper: GH-BP, growth hormone-binding protein; IGF-I, insulin-like growth factor I.

J. Clin. Invest.

(c) The American Society for Clinical Investigation, Inc. $0021-9738 / 93 / 02 / 0629 / 13 \quad \$ 2.00$

Volume 91, February 1993, 629-641 ized low-affinity binding protein that is unrelated to the $\mathrm{GH}$ receptor $(10,11)$. High-affinity GH-BP concentrations are very low or dysfunctional in Laron-type dwarfism $(12,13)$ and decreased in fetal plasma and in certain GH-resistant populations such as pygmies in Africa or the New Guinea highlands $(10,14-16)$. Studies in heterologous species (e.g., injection of human GH-BP complexed with human GH into the rat) indicate that the presence of a high-affinity binding protein (BP) can prolong the apparent half-life of GH in plasma (17-19). Moreover, an intuitive prediction is that plasma GH-BP would damp oscillations engendered by the burstlike secretion of $\mathrm{GH}$ into the plasma compartment, and contribute to the retention of $\mathrm{GH}$ in the circulation $(17,20,21)$. Here, we have tested these intuitive inferences by formulating an explicit mathematical model to evaluate the predicted effects of the high-affinity GH-BP in plasma on the half-life of total, bound, and free $\mathrm{GH}$, and the steady-state and nonequilibrium plasma concentrations of free, bound, and total $\mathrm{GH}$ as a function of the mode (pulsatile vs. continuous) and amount of GH secreted.

\section{Methods}

Computer simulations of $\mathrm{GH}$ dynamics in vivo. As an initial approximation of the dynamics of GH secretion and removal in the absence and presence of a GH-BP, we assumed that a single high-affinity, lowcapacity, and specific GH-BP contributes predominantly to GH binding in plasma, i.e., that any contribution of other low-affinity BPs is relatively small by comparison, as has been shown $(10,11,22)$. In addition, we provisionally assumed that $(a)$ the turnover of the GH-BP is slow compared to that of free GH itself; $(b)$ the intact GH-BP complex is removed at a rate that is slow compared to the clearance of free GH (18); (c) GH and BP mass are conserved; (d) the binding stoichiometry of $\mathrm{GH}$ to its $\mathrm{BP}$ is equimolar ${ }^{2} ;(e)$ the native elimination function for removal of $\mathrm{GH}$ irreversibly from plasma is a single exponential, which acts only on free $\mathrm{GH} ;(f) \mathrm{GH}$ of 22,000-D molecular mass is measured and constitutes the principal circulating form of $\mathrm{GH}$ (23, $24) ;(g)$ both bound and free $\mathrm{GH}$ are measured as immunoreactive $\mathrm{GH}$ $(25) ;(h) \mathrm{GH}$ is secreted in distinct pulses of finite half-duration (duration at half-maximal amplitude), amplitude, and mass; $(i)$ BP concentration/activity is constant over time $(26,27)$; and $(j)$ the fate of a molecule of GH injected into the bloodstream by the anterior pituitary gland includes entry into the free (protein unbound) compartment, possible association with the BP, dissociation from the BP, and/or irreversible elimination of free hormone by metabolic and excretory mechanisms.

2. Recent in vitro studies indicate that a single molecule of $\mathrm{GH}$ can capture two molecules of recombinant GH-BP through two binding sites; see reference 53. It is not clear at present whether such a 2:1 complex occurs in plasma. Evidence to date has indicated a predominantly $1: 1$ stoichiometry for the native complex in plasma. 
Based on earlier in vitro measurements of the equilibrium association of human GH with its natural high-affinity plasma BP and values averaged from several laboratories $(1,2,9,12,20)$, we used an apparent equilibrium $K_{\mathrm{d}}$ of $1.5 \mathrm{mM}$ as a nominal value in most simulations. ${ }^{3}$ In addition, we used a nominal $V_{0}$ for $\mathrm{GH}$ of $7 \%$ body weight (28), a putative $t_{1 / 2}$ of total GH of $18 \mathrm{~min}(29)$, and a mean GH-BP concentration of $1.0 \mathrm{nM}(1,2,9)$. From earlier estimates, we assumed that the daily total secretion of $\mathrm{GH}$ in humans can span an approximate range of $0.11-1.1 \mathrm{mg} / \mathrm{d}(5-50 \mathrm{nmol} / \mathrm{d})$, and that a single GH secretory burst has a mass either 2.2 or $22 \mu \mathrm{g}(0.1$ or $1.0 \mathrm{pmol})$, unless indicated otherwise (30-33).

The association of GH with its BP has been previously reported (1); its rapidity precludes precise estimation of the association rate constant $\left(k_{\mathrm{on}}\right)$ with available technology. Therefore, the much slower dissociation of the complex was measured. To estimate the unidirectional dissociation rate constant (off rate, $k_{\text {off }}$ ) of $\mathrm{GH}$ from the high-affinity $\mathrm{GH}$ BP, pooled adult human serum $(9 \mathrm{ml})$ was preincubated with $\sim 9 \mathrm{ng}$ of monomeric [ ${ }^{125} \mathrm{I}$ ]-human $\mathrm{GH}$ for $2 \mathrm{~h}$ at $37^{\circ} \mathrm{C}$ as described (1). An excess of unlabeled human $\mathrm{GH}(1 \mathrm{mg} /$ liter $)$ was then added in $0.1 \mathrm{ml}$

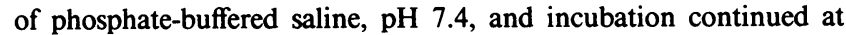
$37^{\circ} \mathrm{C}$. Periodically, aliquots were removed, immediately chilled in an ice-water bath, and free GH was separated from bound GH on Sephadex G-100 columns at $4^{\circ} \mathrm{C}$. Peaks corresponding to the high affinity GH-BP complex and free GH were integrated (1), and bound GH expressed as a function of time after initiation of dissociation. A single rate constant of dissociation was estimated from these measurements as $0.037 / \mathrm{min}(67 \%$ confidence interval $0.030-0.043)$; see Fig. 1. (Attempts to determine the dissociation of the low affinity GH-BP complex [10] in whole plasma were unsuccessful owing to the small percentage of $\mathrm{GH}$ bound to that $\mathrm{BP}$, which rendered precise kinetic estimations difficult.)

The following differential equations were formulated to describe the binding, dissociation, and removal of secreted GH from human plasma. Specifically, given a constant secretion rate, the rates of change of concentrations of free and bound GH over time $(t)$ are given by:

$$
\begin{aligned}
& \frac{\mathrm{d}[\text { free }]}{\mathrm{d} t}=-\left(k_{\mathrm{t}}+k_{\mathrm{on}} \cdot([\mathrm{BP}]-[\text { bound }])\right) \cdot[\text { free }] \\
& +k_{\mathrm{off}} \cdot[\text { bound }]+\frac{S R}{V_{0}} \\
& \frac{\mathrm{d}[\text { bound }]}{\mathrm{d} t}=k_{\mathrm{on}} \cdot([\mathrm{BP}]-[\text { bound }]) \cdot[\text { free }]-k_{\mathrm{off}} \cdot[\text { bound }]
\end{aligned}
$$

And, if we assume that a pulsed injection or secretory burst of GH enters the bloodstream by way of the free compartment, then

$$
\begin{aligned}
& \frac{\mathrm{d}[\text { free }]}{\mathrm{d} t}=-\left(k_{\mathrm{t}}+k_{\mathrm{on}} \cdot([B P]-[\text { bound }])\right) \cdot[\text { free }] \\
& +k_{\mathrm{off}} \cdot[\text { bound }]+\frac{S(t)}{V_{0}} \\
& \frac{\mathrm{d}[\text { free }]}{\mathrm{d} t}=-\left(k_{\mathrm{t}}+k_{\mathrm{on}} \cdot([B P]-[\text { bound }])\right) \cdot[\text { free }] \\
& +k_{\mathrm{off}} \cdot[\text { bound }]+\frac{1}{V_{0}} \sum_{\mathrm{i}=1}^{\mathrm{N}} \text { ampl }(i) \cdot \exp \left(-\frac{1}{2}\left[\frac{t-t(\mathrm{i})}{\sigma}\right]^{2}\right)
\end{aligned}
$$

These constructs assume that in plasma $\mathrm{GH}$ is either bound or free, where [free], [bound], and [BP] represent the concentrations $(\mathrm{M})$ of

3. A relatively wide range of $K_{\mathrm{d}}$ values is reported for different in vitro incubation and separation conditions of human $\mathrm{GH}$ binding in plasma or various buffer systems: viz. from $0.25 \mathrm{nM}$ (Michael J. Waters, Queensland, Australia) to $5.0 \mathrm{nM}$ (reviewed in reference 24). We have the nominal value of $1.5 \mathrm{nM}$ for most of the present work.

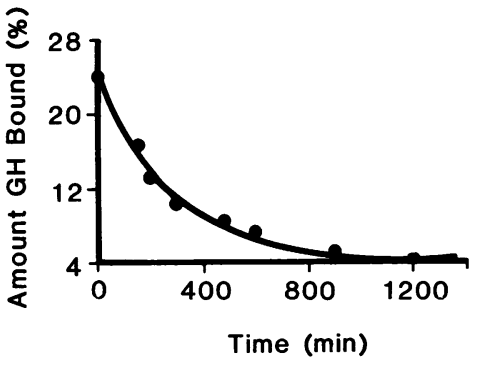

free GH, bound GH, and BP, respectively; $S$ designates the secretory pulse function with a half-duration of sigma times 2.354 , and amplitude of ampl (i); SR denotes the basal secretion rate of $\mathrm{GH}$ ( $\mathrm{mol} / \mathrm{min})$, if any; $V_{0}$ denotes the distribution volume (liters); $k_{t}\left(\mathrm{~min}^{-1}\right)$ is the rate constant for $\mathrm{GH}$ to $\mathrm{BP}\left(\mathrm{M}^{-1} \mathrm{~min}\right) ; k_{\text {off }}$ is the dissociation rate constant (which is related to its $t_{1 / 2}$ by $\ln 2 / k_{1}, \min$ ); $k_{\text {on }}$ is the association rate constant for $\mathrm{GH}$ to $\mathrm{BP}\left(\mathrm{M}^{-1} / \mathrm{min}\right) ; k_{\text {of }}$ is the dissociation rate constant $\left(\min ^{-1}\right)$; and $k_{\mathrm{d}}$ is the equilibrium dissociation constant, which equals $k_{\text {off }} / k_{\text {on }}(\mathrm{M})$.

The above differential equations were solved using the RungeKutta formulas as implemented for first-order differential equations (34).

\section{Results}

Equilibrium conditions. As a first approximation, we investigated GH kinetics under equilibrium conditions, although under physiological circumstances such conditions rarely apply. As shown in Table I, different mean daily GH secretion rates within and exceeding the approximately physiological range observed in the human across various age spans and body weights yield a correspondingly broad range of total, free, and bound $\mathrm{GH}$ concentrations in plasma at theoretical equilibrium. Varying the mean secretion rate of $\mathrm{GH}$ influences the apparent equilibrium plasma concentrations of free, bound, and total $\mathrm{GH}$, and the percentage occupancy of the BP, but less markedly the percentage of $\mathrm{GH}$ bound to the BP. The latter decreases slightly (from $39 \%$ to $33 \%$ ) when the mean GH secretion rate is increased 10 -fold above the nominal normal value in humans.

Table I also shows the influence of altering the equilibrium dissociation constant. Using the approximate literature value for the equilibrium dissociation constant, namely a $k_{\mathrm{d}}$ of 1.5 $\mathrm{nM},{ }^{3}$ and our measured $k_{\text {of }}$ of $0.037 / \mathrm{min}$, we observed that BP affinity for $\mathrm{GH}$ influences the total and bound concentrations of $\mathrm{GH}$ in plasma, the percentage of $\mathrm{GH}$ bound, and the percentage occupancy of the GH-BP, but not the concentration of free GH. Alternatively, altering the apparent capacity of the BP modifies the concentrations of total and bound GH and percentage of $\mathrm{GH}$ bound at any given moment, but does not influence the concentration of free $\mathrm{GH}$ or the percentage occupancy of the BP.

The $t_{1 / 2}$ of free $\mathrm{GH}$ within the physiological range influences the concentrations of free and bound $\mathrm{GH}$ in plasma, the $t_{1 / 2}$ of total GH, and the percentage of BP that is occupied, but minimally affects the percentage of GH bound; see Table I.

The above results can also be stated in relation to factors that control free, bound, and total GH concentrations, and the percentages of GH bound and of BP occupied in plasma; see Table I. Specifically, the apparent concentration of free $\mathrm{GH}$ at equilibrium is controlled positively by the secretion rate and 
Table I. Estimated Molar Concentrations and Percentages of Free and Bound GH in Plasma at Equilibrium in the Presence of Varying Amounts and/or Affinities of GH-BP and Different Simulated Conditions

\begin{tabular}{|c|c|c|c|c|c|c|}
\hline \multirow[b]{3}{*}{ Simulated BP properties } & \multirow[b]{3}{*}{ GH secretion rate } & \multirow{2}{*}{\multicolumn{3}{|c|}{$\begin{array}{l}\text { Predicted steady-state } \\
\text { serum GH concentrations }\end{array}$}} & \multicolumn{2}{|c|}{ Percentages } \\
\hline & & & & & \multirow{2}{*}{$\begin{array}{c}\text { GH } \\
\text { bound to } \\
\text { protein }\end{array}$} & \multirow{2}{*}{$\begin{array}{c}\text { BP } \\
\text { occupied }\end{array}$} \\
\hline & & Total & Free & Bound & & \\
\hline & $\mathrm{pmol} / \mathrm{min}$ & & $p M$ & & & \\
\hline Nominal* & 10 & 34.2 & 20.6 & 13.6 & 39.8 & 1.3 \\
\hline Double the BP affinity & 10 & 47.4 & 20.6 & 26.8 & 56.5 & 2.6 \\
\hline Double the BP concentration & 10 & 47.4 & 20.6 & 26.8 & 39.8 & 1.3 \\
\hline Halve the BP concentration & 10 & 27.4 & 20.6 & 6.8 & 39.8 & 1.3 \\
\hline Complete absence of BP & 10 & 20.6 & 20.6 & 0 & 0 & 0 \\
\hline Nominal but secretion rate doubled & 20 & 68 & 41.2 & 26.8 & 39.4 & 2.6 \\
\hline Nominal but secretion rate increased 10 -fold & 100 & 327 & 206 & 121 & 37.0 & 12.1 \\
\hline Nominal but GH half-life doubled & 10 & 68.0 & 41.2 & 26.8 & 39.4 & 2.6 \\
\hline Nominal but GH half-life halved & 10 & 17.1 & 10.3 & 6.8 & 39.4 & 0.65 \\
\hline Volume of distribution doubled & 10 & 17.1 & 10.3 & 6.8 & 39.8 & 0.65 \\
\hline
\end{tabular}

* Assuming: a nominal free GH half-life of $7 \mathrm{~min}$ in the absence of BP, which corresponds to a total GH half-life of $18 \mathrm{~min}$ in the presence of BP; a GH distribution volume of 4.9 liters or $7.0 \%$ in a 70-kg man; a plasma GH-BP concentration of $1 \mathrm{nM}$ with an equilibrium binding constant $\left(K_{\mathrm{d}}\right)$ of $1.5 \mathrm{nM}$ and an off-rate constant $\left(\mathrm{k}_{\text {off }}\right)$ of $0.037 \mathrm{~min}^{-1}$; a nominal daily $\mathrm{GH}$ secretion rate of $314 \mu \mathrm{g}$, which corresponds to $\sim 10 \mathrm{pmol} / \mathrm{min}$ of GH secretion. Given a GH molecular mass of $22,000 \mathrm{D}$, then $45 \mathrm{pM}$ is $1 \mu \mathrm{g} /$ liter.

$t_{1 / 2}$ of $\mathrm{GH}$ and negatively by the value of the $V_{0}$, but is not influenced by the binding properties of the GH-BP. The concentrations of bound and total GH are controlled by the GH secretion rate and $t_{1 / 2}$, and the binding affinity and capacity of the BP. The percentage of GH bound at equilibrium is specified by the BP affinity and capacity, but not the $t_{1 / 2}$ or SR within the physiological range. Finally, the percentage of GHBP that is occupied at steady state is stipulated by the GH secretion rate, $t_{1 / 2}$, and $V_{0}$ and by the affinity of the BP but not its capacity.

The above computer-simulation data apply to steady-state conditions, which can be achieved by infusions of exogenous $\mathrm{GH}$, but are rarely if ever attained spontaneously under physiological conditions in vivo $(30-33,35)$. A plausible pathological exception at least over short time spans (minutes) may be patients with GH-secreting pituitary tumors, since the latter appear to exhibit intervals of tonic or basal secretion upon which may be superimposed high frequency bursts of GH release (36). As shown in Fig. 2, decay from some given steady-state plasma concentration of free, bound, or total GH is influenced by the presence of a GH-binding element in plasma. The absolute value of the rate constant for an approximated monoexponential decay structure depends upon the amount and binding properties of the GH-BP, the $t_{1 / 2}$ of free GH removal, and the starting concentrations of free and bound $\mathrm{GH}$ in plasma. For example, for three different starting concentrations of total GH in plasma, namely 11,34 , and $101 \mathrm{pM}$, generated respectively by mean daily secretion rates of $\mathrm{GH}$ of $0.11,0.33$, and 1.1 $\mathrm{mg} / 24 \mathrm{~h}(4,15$, and $40 \mathrm{nmol} / 24 \mathrm{~h})$, we find by monoexponential approximation the apparent $t_{1 / 2}$ values shown in Table II. These values fall within the wide range of measured GH kinetics reported in the available literature (reviewed in references 29 and 33). Fig. 3 gives the monoexponential approximation for bound, total, and free plasma GH half-lives in the presence vs. absence of $\mathrm{BP}$, assuming a range of free $\mathrm{GH}$ half- lives in the absence of a BP. Note that a free $\mathrm{GH} t_{1 / 2}$ of $\sim 7 \mathrm{~min}$ in the absence of BP corresponds to $a t_{1 / 2}$ of $18 \mathrm{~min}$ for total GH when the BP is present in physiological concentrations.

Nonequilibrium conditions. We next simulated the more complex nonequilibrium conditions that are more akin those occurring physiologically. The predicted dynamic effects of the BP on the plasma concentrations of free, bound, and total GH over time generated by a secreted pulse of GH are shown in Fig. 4. In response to a single pulse of $\mathrm{GH}$, the plasma concentration of free GH increases rapidly, and decays rapidly initially because of removal by irreversible metabolic clearance as well as by association with BP in plasma. The concentration of bound $\mathrm{GH}$ increases almost as rapidly, but decays considerably more slowly because molecules of GH dissociate from the BP at a finite rate while some additional molecules of $\mathrm{GH}$ continue to associate with the BP. The plot of total GH concentrations over time is also considerably more extended than the profile of free hormone for the same reason. Of interest, the percentage of GH that is bound to plasma BP begins at 39\% (assumed equilibrium approximation of previous secretion events), and declines rapidly as the free $\mathrm{GH}$ concentration increases during a pulse of GH delivery into the bloodstream. The percentage of GH bound to BP then increases over the succeeding minutes, and thereafter begins to fall as $\mathrm{GH}$ dissociates from the specific BP reservoir.

Fig. 5 (left panels) illustrates the dynamics of two different GH pulse masses, namely $2.2 \mu \mathrm{g}(0.1 \mathrm{nmol})$ and $22 \mu \mathrm{g}(1.0$ $\mathrm{nmol}$ ). Table III gives the times to maximal values for free, bound, and total plasma GH concentrations in relation to the three different amounts (nanomoles per burst) of GH injected into the bloodstream. As predicted intuitively, free plasma GH concentration peaks first, followed by the bound and total GH concentrations. We also simulated the effect of a nearly instantaneous burst of GH into the bloodstream. Here we assumed a half-duration (duration of the secretion event at half-maximal 
Total
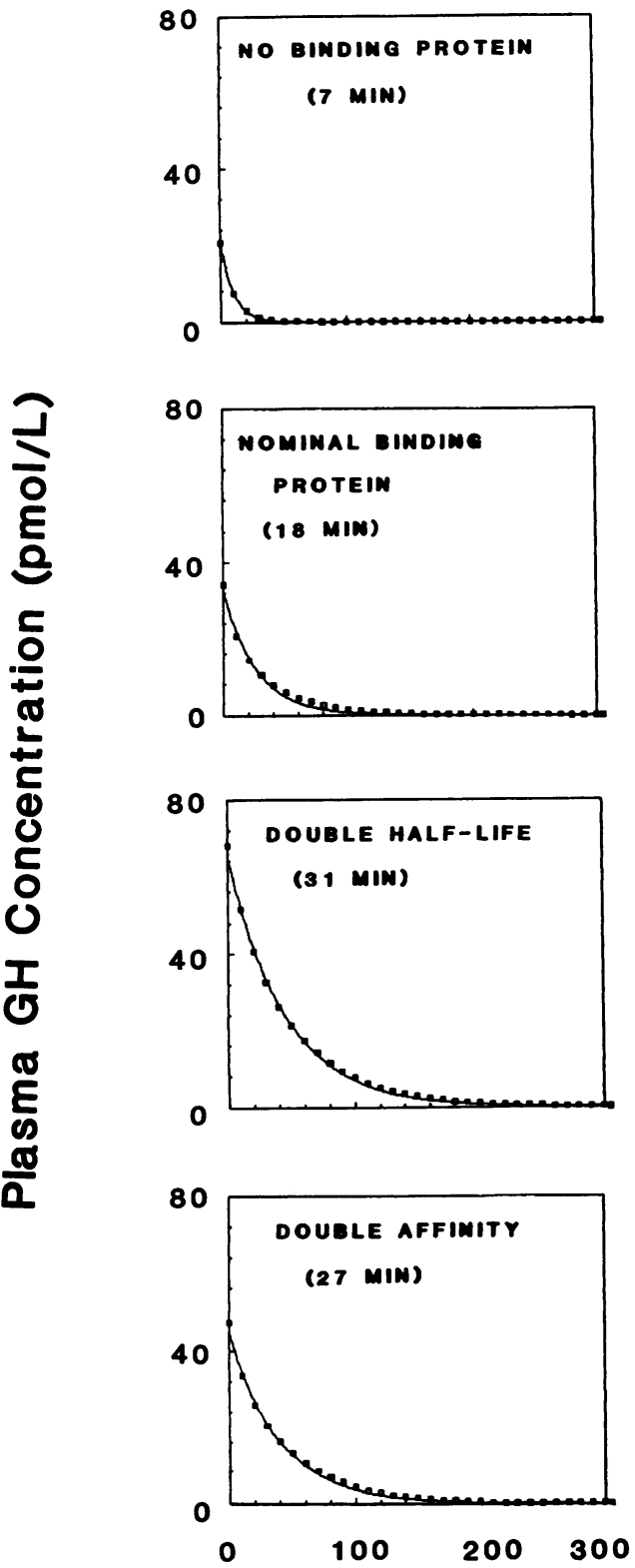

Bound
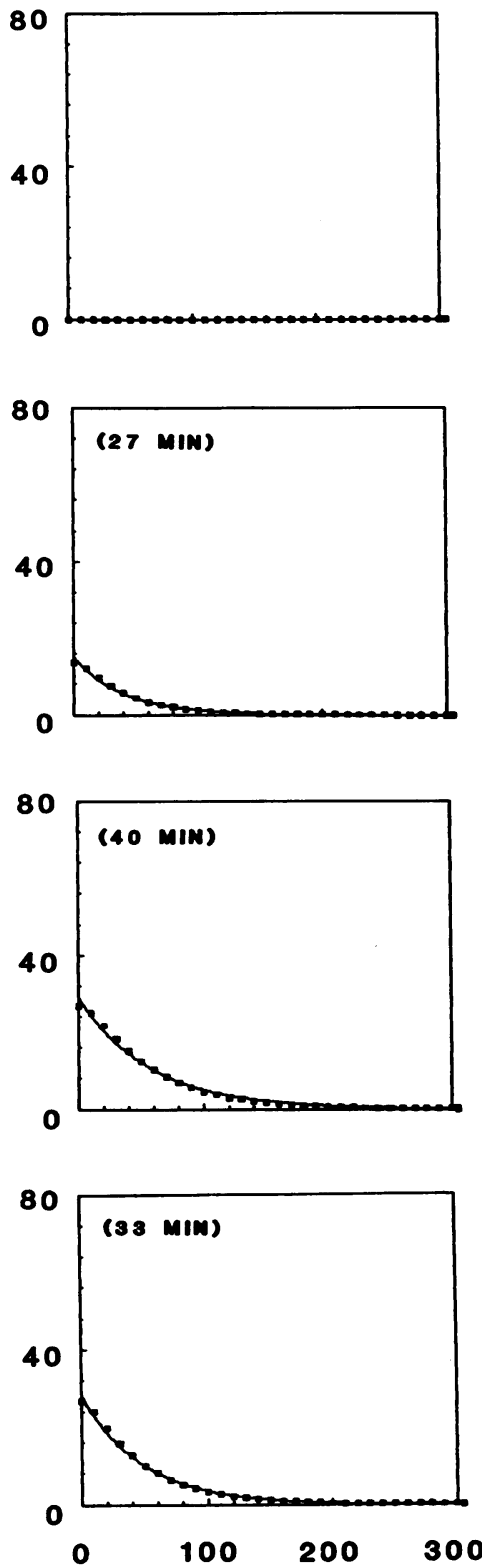

Free
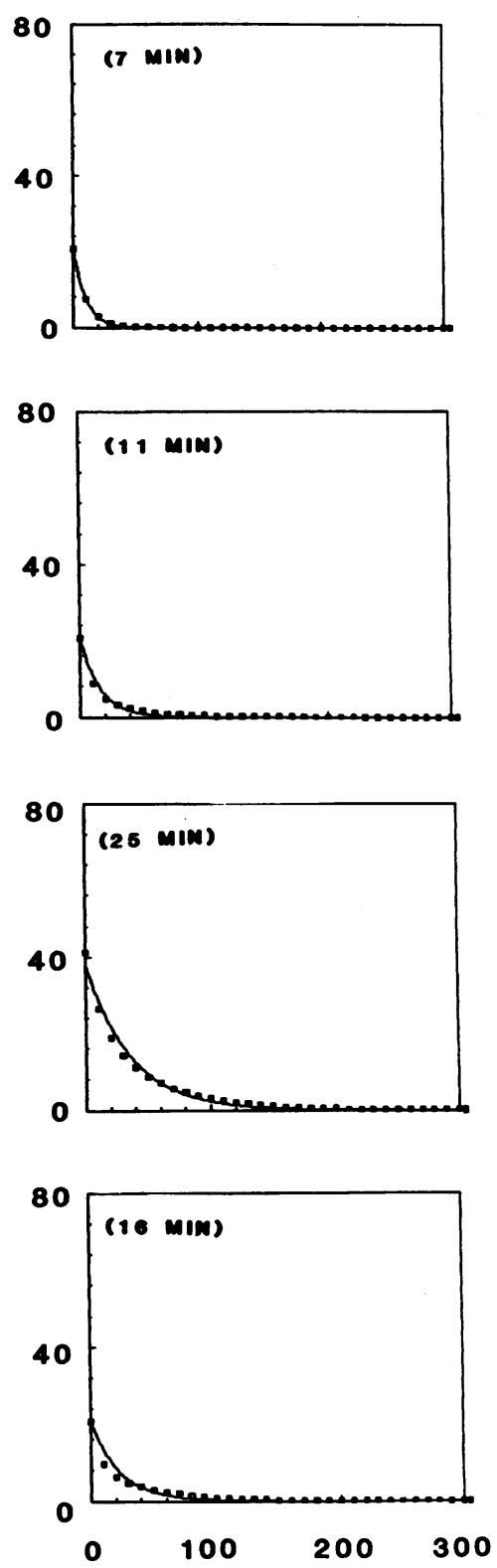

\section{Time (min)}

Figure 2. Predicted time courses of total, bound, and free plasma GH concentrations after decay from a steady-state $\mathbf{G H}$ infusion rate of 10 $\mathrm{pmol} / \mathrm{min}(314 \mu \mathrm{g} / \mathrm{d})$ assuming a $V_{\mathrm{o}}$ of $4.9 \mathrm{~L}$ and a GH molecular mass of 22,000 D. Four simulations are shown: (top) with no BP present and a free GH $t_{1 / 2}$ of $7 \mathrm{~min}$ (which would correspond to a total GH $t_{1 / 2}$ of $18 \mathrm{~min}$ in the presence of BP); (second row from top) in the presence of a BP with $K_{\mathrm{d}}=1.5 \mathrm{nM}$, capacity $1.0 \mathrm{nM}$, and $k_{\text {off }}=0.037 / \mathrm{min}$; (second row from bottom) a similar BP but with a $t_{1 / 2}$ of free GH of 14 min (total GH $t_{1 / 2} 31 \mathrm{~min}$ ); and (bottom) a similar BP with a $K_{\mathrm{d}}$ of $0.75 \mathrm{nM}$ (double the affinity). The $t_{1 / 2}$ values shown on the figure are from approximated monoexponential fits of the simulated decay data. These theoretical curves are subject to the assumptions of conservation of GH mass, irreversible metabolic removal of free hormone only, and a 1:1 stoichiometry of GH binding to its BP at a concentration of $1.0 \mathrm{nM}$. As a first approximation, the GH-BP complex was assumed to be formed $\left(k_{\text {on }}=2.47 \times 10^{7} \mathrm{M}^{-1} \mathrm{~min}\right)$, remain intact, or dissociate $\left(k_{\mathrm{off}}=0.037 /\right.$ min), but not undergo irreversible metabolic removal.

amplitude) of one minute. One-tenth of the daily production rate of GH was "injected" in this single pulse ( $22 \mu \mathrm{g}$ or $1 \mathrm{nmol}$, as above). Note that the plasma concentrations of free and bound GH under these conditions increase to considerably higher absolute values, and that the duration of the total plasma $\mathrm{GH}$ concentration pulse is abbreviated. Comparison of a 1 - and 30-min secretory burst is shown in Fig. 5 (right panels).

We next evaluated the effects of four different half-lives of free GH on the profiles of free, bound, and total GH concentra- 


\begin{tabular}{|c|c|c|c|c|c|c|}
\hline & \multicolumn{3}{|c|}{ Estimated half-lives* } & \multicolumn{3}{|c|}{ Concentrations at steady-state } \\
\hline & Total & Bound & Free & Total & Bound & Free \\
\hline & & $\min$ & & & $p M$ & \\
\hline \multicolumn{7}{|l|}{ Secretion rates ${ }^{\ddagger}$} \\
\hline $314 \mu \mathrm{g} / \mathrm{d}(10 \mathrm{pmol} / \mathrm{min})$ & 18 & 29 & 9 & [34] & [13] & [21] \\
\hline $104 \mu \mathrm{g} / \mathrm{d}(3.33 \mathrm{pmol} / \mathrm{min})$ & 18 & 29 & 9 & [11] & [4.5] & [6.5] \\
\hline $942 \mu \mathrm{g} /$ day $(30 \mathrm{pmol} / \mathrm{min})$ & 18 & 29 & 9 & {$[101]$} & [39] & [62] \\
\hline \multicolumn{7}{|l|}{ Half-lives $^{\ddagger}$} \\
\hline $3.5 \mathrm{~min}$ & 13 & 25 & 4.3 & [17] & [7] & [10] \\
\hline $7.0 \mathrm{~min}$ & 18 & 29 & 9 & [34] & [14] & [21] \\
\hline $14 \min$ & 29 & 43 & 22 & [68] & [27] & [41] \\
\hline \multicolumn{7}{|l|}{ GH-BP } \\
\hline Absent & 7 & None & 7 & {$[21]$} & {$[0]$} & [21] \\
\hline Twice the capacity & 25 & 35 & 16 & [48] & [27] & [27] \\
\hline Twice the nominal affinity ${ }^{\ddagger}$ & 25 & 35 & 16 & [48] & [27] & [21] \\
\hline
\end{tabular}

* Values are fitted GH half-lives in the indicated compartments after abrupt cessation of equilibrated continuous secretion of GH at the indicated rate (or otherwise, $314 \mu \mathrm{g} / \mathrm{d}=10 \mathrm{pmol} / \mathrm{min}$ ). ${ }^{\ddagger}$ Theoretical decay half-time of free hormone in the absence of BP was assumed to be 7 min or as indicated. Also assumed are a distribution volume of 4.9 liters, a GH-BP concentration of $1.0 \mathrm{nM}$ and $K_{\mathrm{d}}$ of $1.5 \mathrm{nM}$. Note that once a BP is introduced, the half-life of free GH is controlled by both the removal rate of unbound GH and the binding properties of the BP.

tions in plasma. We used nominal half-lives of free $\mathrm{GH}$ of 4,9 , 18, and 36 (Fig. 6). The corresponding approximate half-lives of total $\mathrm{GH}$ are $16,21,37$, and 63 min, values which cover the range reported in the literature for physiological and pathological conditions. One-tenth of the daily $\mathrm{GH}$ secretion rate was injected as a single pulse in these simulations $(22 \mu \mathrm{g}$ or 1 nmol). Note that the times to maximum and the maximal values of the plasma concentrations of free, bound, and total GH are strongly controlled by the apparent half-life of free $\mathrm{GH}$ in plasma; see Table III.

The pathophysiological impact of decreased plasma GHBP concentrations on pulsatile free, total, and bound GH concentrations over time is illustrated in Fig. 7 (left panels), which compares GH profiles over $24 \mathrm{~h}$ in a normal male (nominal GH-BP concentration $1.0 \mathrm{nM}$ ) and a patient with insulin-dependent diabetes mellitus (mean GH-BP concentration 0.725 $\mathrm{nM}$ ). Nonlinear curve-fitting of the total plasma GH concentrations measured in samples collected at 10 -min intervals for $24 \mathrm{~h}$ showed significant increases in $\mathrm{GH}$ secretion rates and free GH concentrations in diabetes mellitus, and a decrease in total

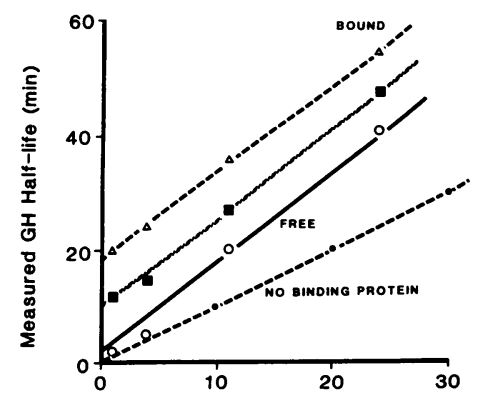

Theoretical Half-life of Free $\mathrm{GH}(\mathrm{min})$ approximation of GH halflives for bound, total, and free GH given the nominal GH-BP model summarized various theoretical halflives of free GH in the absence of a BP. The line with the filled squares corresponds to total GH.
Figure 3. Monoexponential in Fig. 2, and assuming but not free GH half-life as predicted by the kinetic model. Conversely, the effects of increased serum GH-BP concentrations are shown for comparison in Fig. 7 (right panels), which depicts 24-h serum GH concentration profiles obtained by sampling blood at 10 -min intervals for $24 \mathrm{~h}$ in an obese middleaged man and a nonobese age-matched control. Assuming a blood GH-BP concentration of $1.7 \mathrm{nM}$ in the obese (vs. $1.0 \mathrm{nM}$ in the normal weight) subject, we used deconvolution analysis to determine the half-life of total and free $\mathrm{GH}$, the time-course of plasma GH secretion, and the resultant plasma concentrations of free GH, bound GH, and total GH. The last-mentioned values were compared to measured concentrations of total GH; see Fig. 7 (right panels).

The dynamic changes in $\mathrm{GH}$ binding over $24 \mathrm{~h}$ in the above subjects are illustrated in Fig. 8. Note that in the healthy, obese, and diabetic men, the percentage of $\mathrm{GH}$ bound to high-affinity BP varies from $10 \%$ to $80 \%$ over the course of $24 \mathrm{~h}$. Of particular interest, during intervals of secretory quiescence (i.e., between successive GH secretory bursts), the percentage of GH bound increases progressively, which reflects the reservoir-like and buffering capacity of GH-BP. Conversely, during individual GH secretory bursts, the free concentration of GH increases rapidly and the percentage of bound GH falls with a consequently increased availability of GH to metabolic removal. These dynamics apply to the normal, diabetic, and obese profiles.

\section{Discussion}

To evaluate the dynamics of GH secretion into, removal from, and partitioning within plasma, we formulated a model that assumed either the attainment of equilibrium plasma $\mathrm{GH}$ concentrations (e.g., achieved by constant infusion of exogenous $\mathrm{GH}$, or tonic $\mathrm{GH}$ secretion in patients with $\mathrm{GH}$-secreting pitu- 

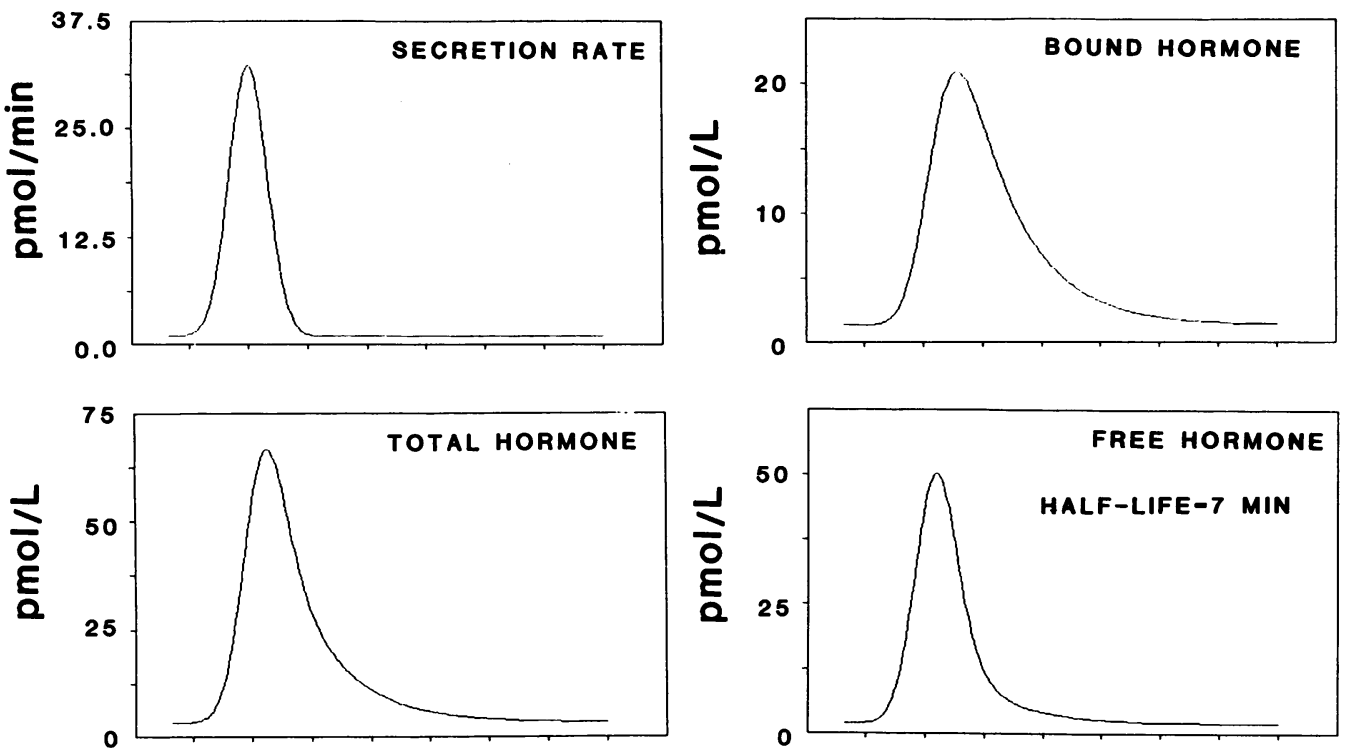

Figure 4. Time courses of calculated GH secretory rate, total, bound and free plasma GH concentrations, and percentages of $\mathrm{GH}$ bound and protein occupied assuming: (a) a high-affinity plasma GH-BP $\left(k_{\mathrm{d}}=1.5 \mathrm{nM}\right.$, capacity $=1.0 \mathrm{nM}) ;(b)$ a distribution volume of 4.9 liters; (c) a total GH $t_{1 / 2}$ of $18 \mathrm{~min}$; (d) a molecular mass of $\mathrm{GH}$ of $22,000 \mathrm{D}$; $(e)$ a $k_{\text {off }}$ of $0.037 / \mathrm{min}$; and $(f)$ a symmetric (Gaussian) GH secretory burst with a half-duration (duration at half-maximal amplitude) of $30 \mathrm{~min}$ centered about zero and a mass of $1 \mathrm{nmol}(22 \mu \mathrm{g})$; see Methods. For ease of visualization, the curves have been elevated to reflect a low rate of constant basal secretion ( 1 Time (min) $\mathrm{pmol} / \mathrm{min}$ )

itary tumors), or a physiologically pulsatile mode of $\mathrm{GH}$ release, characterized by abrupt bursts of $\mathrm{GH}$ release into the bloodstream. To this end, we measured the unidirectional rate constant for GH dissociation from its BP in vitro $(\sim 0.037 /$ $\mathrm{min}$ ), and used available earlier estimates of the equilibrium dissociation constant of $\mathrm{GH}$ from its $\mathrm{BP},{ }^{3}$ the total binding capacity of the GH-BP in human plasma, and an assumed 1:1 stoichiometry for $\mathrm{GH}$ binding. ${ }^{2}$ For quantitative purposes, we carried out computer simulations to define the equilibrium as well as the nonequilibrium characteristics of $\mathrm{GH}$ binding and disposal over time in the presence or absence of a specific highaffinity GH-BP, given various assumed half-lives for the removal of free $\mathrm{GH}$ from plasma, plausible $\mathrm{GH}$ secretion rates and secretory pulse waveforms, different BP affinities and capacities, and different apparent $V_{0}$ 's for $\mathrm{GH}$.

Our analyses demonstrate that certain intuitive predictions of the effects of GH-BP on the dynamics of GH secretion, distribution, and clearance can be corroborated quantitatively. Indeed, we identified specific predictors of plasma concentrations of free, bound, and total $\mathrm{GH}$, the percentage of $\mathrm{GH}$ bound to plasma BP at any given instant, and the percentage of BP occupied by GH. The steady-state predictions given here correspond simply to those of a two-compartment kinetic model, and are to be anticipated only during continuous (exogenous) GH infusions, or in selected pathophysiology (e.g., some patients with acromegaly who have high rates of basal GH secretion with no or few superimposed pulses). In addition, we posited a model combining pulsatile (i.e., nonequilibrium) GH secretion and stable amounts of the GH-BP in plasma in order to mimic physiological conditions of burstlike pituitary GH secretion. This construct of pulsatile ligand secretion and association with and dissociation from a high-affinity BP in plasma is schematized in Fig. 9, and offers novel predictions that are relevant to any protein, metabolite, or substrate injected into the bloodstream with a defined time course, when that ligand can bind to one or more specific (high or low affinity) BPs in the plasma compartment. Moreover, our dynamic model can be expanded to conditions in which either the unoccupied BP or ligand-BP complexes are themselves removed from the circulation, and/or to situations where higher-order exponential kinetics exist for the removal of free, bound, or total ligand from plasma.

Under the simplifying assumptions of full equilibration, conservation of mass, and clearance of free hormone only, we found that the $V_{0}$, mean GH secretory rate, and the $t_{1 / 2}$ of free hormone all substantially affect the steady-state concentrations of free and bound (and total) GH, as well as the percentage of BP occupied. These parameters influence the percentage of $\mathrm{GH}$ bound considerably less. In addition, whereas the BP affinity influences the amount (concentration and percentage) of 

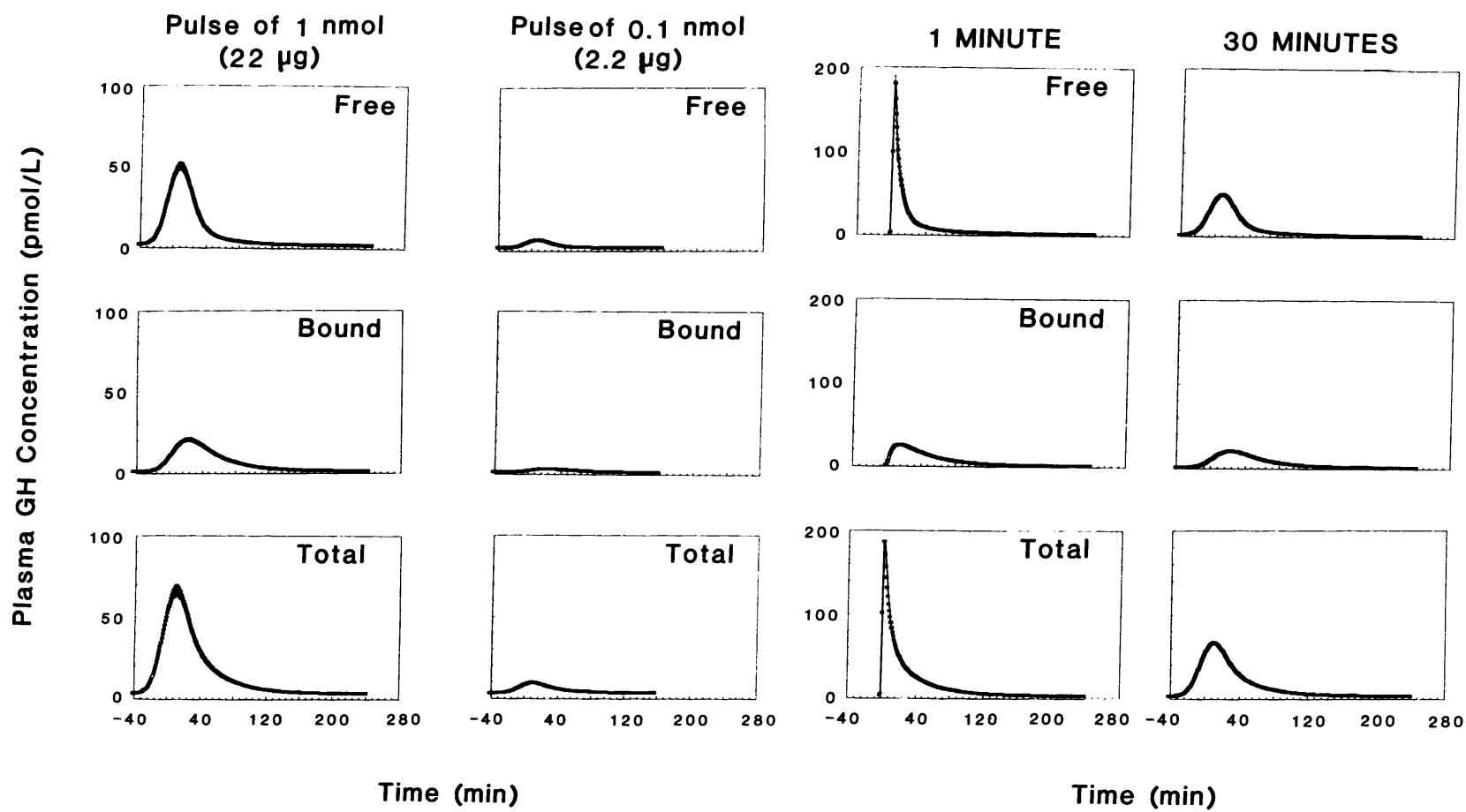

Figure 5. (Left panels) Computer simulation of a hypothetical GH secretory burst containing specified amounts of GH within the presumptive physiological range. A single burst of GH secretion was simulated and centered about time zero (abscissa). The total mass of GH delivered in the burst was either $1 \mathrm{nmol}(22 \mu \mathrm{g}$, left column $)$, or $0.1 \mathrm{nmol}(2.2 \mu \mathrm{g}$, right column $)$. The $\mathrm{GH}$ secretory burst was simulated algebraically by a Gaussian distribution of $\mathrm{GH}$ secretion rates, in which the half-duration (time in minutes elapsing in half-maximal amplitude) was 30 min. The vertical axis gives the calculated plasma GH concentration in pmol/L (pM). In each column three curves are shown to denote the expected time courses of free, bound, and total GH assuming the nominal parameters given in Fig. 4. (Right panels) Time course of predicted plasma GH concentration profiles after a presumptively physiologic secretory burst ( right column) compared to a nearly instantaneously secretory event (left column), which were assigned respective half-durations (duration in minutes of the secretion episode at half-maximal amplitude) of 30 min or $1 \mathrm{~min}$. Results are presented otherwise as described for left panels.

Table III. Peak GH Secretory Rates, Times to Maximal Values, and Maximal Plasma GH Concentrations after a Single Intravenous Pulse of $G H$

\begin{tabular}{|c|c|c|c|c|c|c|c|}
\hline & \multirow{2}{*}{$\begin{array}{l}\text { Peak secretory } \\
\text { rate }\end{array}$} & \multicolumn{3}{|c|}{ Times to maximal values } & \multicolumn{3}{|c|}{ Maximal plasma GH concentrations } \\
\hline & & Free & Bound & Total & Free & Bound & Total \\
\hline & $\mathrm{pmol} / \mathrm{min}$ & & $\min$ & & & $p M$ & \\
\hline \multicolumn{8}{|c|}{ Mass of GH pulse, $\mu \mathrm{g}(\mathrm{nmol})$} \\
\hline $22(1.0)$ & 32 & 7 & 23 & 10 & {$[50]$} & {$[21]$} & [67] \\
\hline $2.2(0.1)$ & 3.2 & 7 & 23 & 10 & [5] & {$[2]$} & [7] \\
\hline $0.22(0.01)$ & 0.32 & 7 & 23 & 10 & {$[0.5]$} & {$[0.2]$} & [0.7] \\
\hline \multicolumn{8}{|c|}{ Free GH half-life (total GH half-life) } \\
\hline $4(16)$ & 32 & 4 & 19 & 7 & [33] & [13] & [43] \\
\hline $7(18)$ & 32 & 7 & 23 & 10 & {$[50]$} & [21] & [67] \\
\hline $9(21)$ & 32 & 9 & 25 & 11 & [59] & {$[25]$} & [79] \\
\hline $18(37)$ & 32 & 12 & 31 & 15 & [86] & [39] & [117] \\
\hline $36(63)$ & 32 & 16 & 38 & 20 & [114] & [54] & [158] \\
\hline \multicolumn{8}{|c|}{ GH secretory burst half-duration (min) } \\
\hline 1 & 880 & 1 & 16 & 1 & {$[180]$} & [26] & [190] \\
\hline 30 & 32 & 7 & 23 & 10 & [50] & [21] & [67] \\
\hline 50 & 18 & 9 & 27 & 13 & {$[34]$} & {$[17]$} & [49] \\
\hline
\end{tabular}

Values are peak secretory rates and times $(\mathrm{min})$ to maximal values of free, bound, or total plasma GH concentrations assuming a single Gaussian secretory burst centered at time zero with a half-duration (duration at half-maximal amplitude) of $30 \mathrm{~min}$, a mass of $22 \mu \mathrm{g}(1 \mathrm{nmol}$ ), a distribution volume of 4.9 liters, a half-life of total GH of $18 \mathrm{~min}$ (corresponding to a free GH half-life in the absence of BP of $7 \mathrm{~min}$ ), and a BP concentration of $1.0 \mathrm{nM}$ and equilibrium $K_{\mathrm{d}}$ of $1.5 \mathrm{nM}$, except where indicated otherwise. Note that the time-to-peak values differ for free, bound, and total $\mathrm{GH}$, and hence the maximal values given in the last three columns do not simply sum. 
Half-life

$36 \mathrm{~min}$

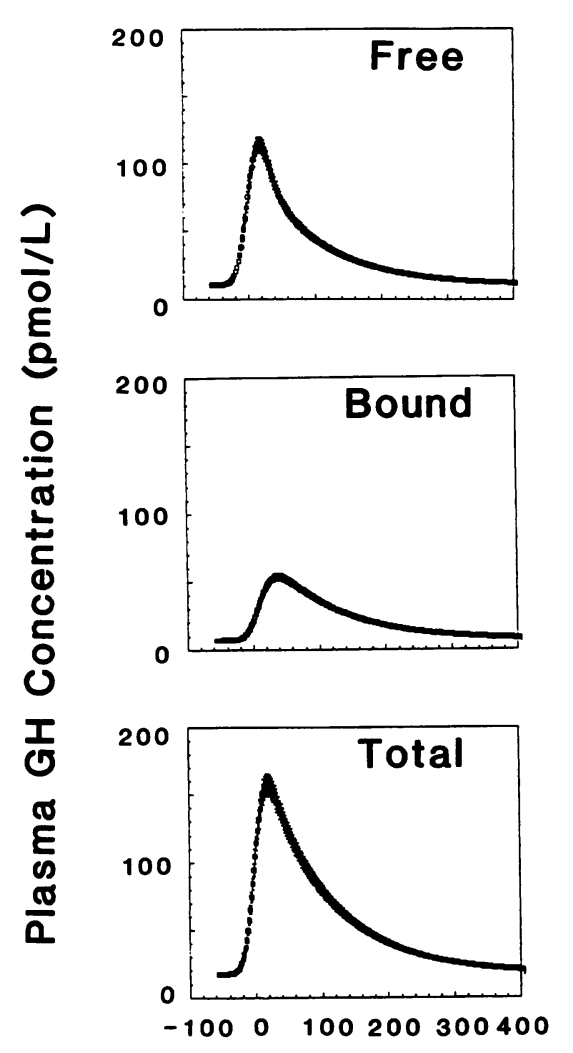

Half-life

$18 \mathrm{~min}$
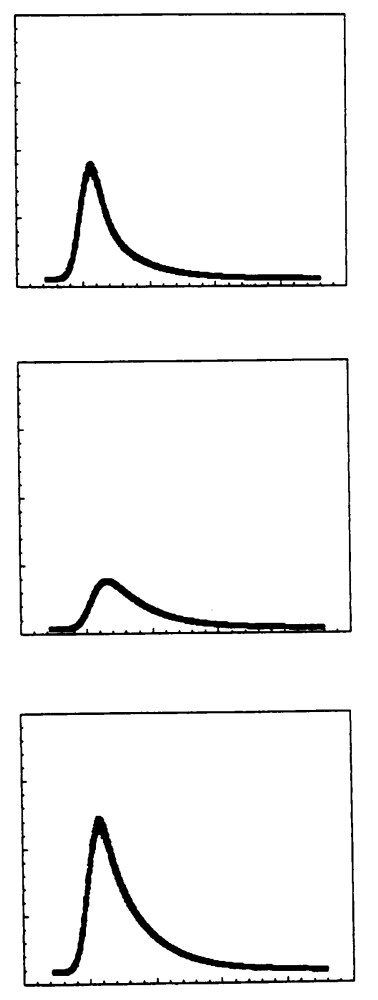

Half-life

$9 \mathrm{~min}$
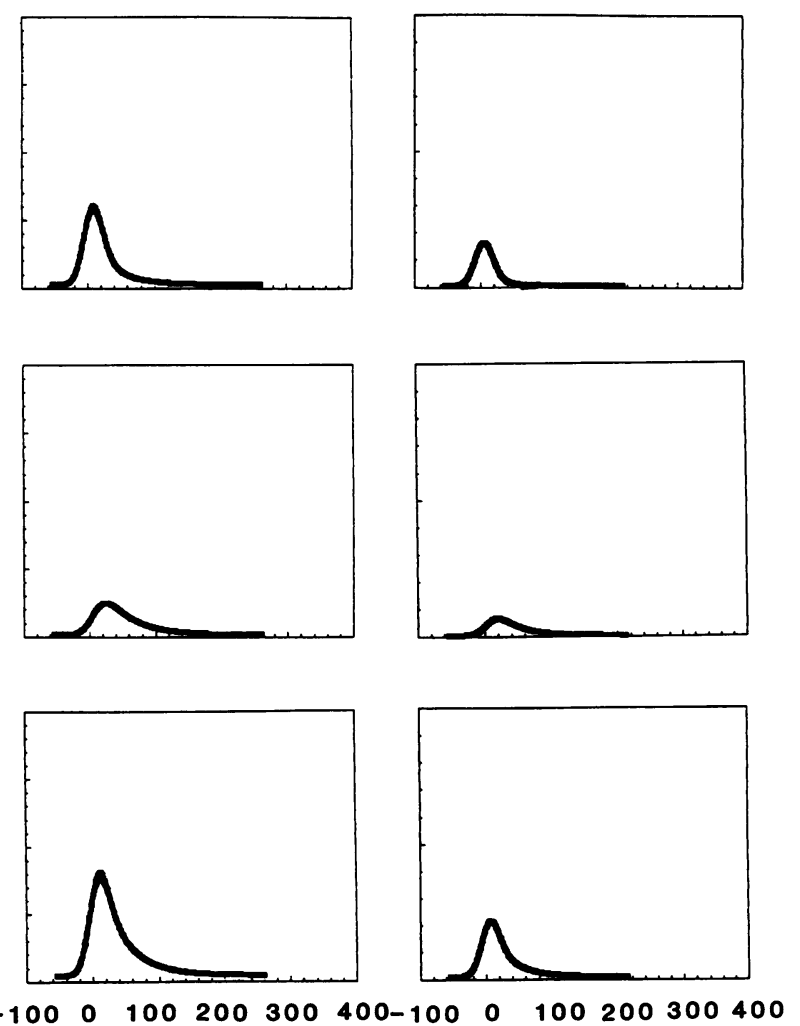

Time (min)

Figure 6. Influence of different free GH half-lives on the profiles of plasma free, bound, and total GH concentrations following a hypothetical GH secretory burst. The hypothetical GH secretory burst with a mass of $1 \mathrm{nmol}(22 \mu \mathrm{g})$ is described in Fig. 5 (left panels). The four columns of panels depict the anticipated plasma concentrations of free, bound, and total GH assuming monoexponential decay rates of free GH in the absence of BP corresponding to half-lives of $36,18,9$, or 4 min which correspond to total GH half-lives of $63,37,21$, and 16 min, respectively.

The last two values bracket the physiological range for published half-lives for total $\mathrm{GH}$ in humans.

hormone bound and also the percentage of BP occupied by hormone, the free concentration of ligand at equilibrium is not controlled by the BP affinity. In contrast, the capacity (i.e., concentration ) of the BP affects the concentration and percentage of hormone bound, but does not modify the steady-state free hormone concentration or the percentage of BP occupied by its ligand. These general inferences apply qualitatively to other ligand-circulating receptor interactions, under similar simplifying assumptions.

If the concentration of free hormone is primarily responsible for hormone action in target tissues, then factors that control the free hormone concentration in plasma are of particular interest. We observed that only the secretion rate, $t_{1 / 2}$, and $V_{0}$ of the hormone contribute substantially to the equilibrium concentration of free ligand in plasma. BP affinity or capacity do not markedly influence the free hormone concentration at steady state within physiological ranges of hormone secretion rates or half-lives. Indeed, complete absence of the BP does not modify the free hormone concentration at steady-state for any given secretion rate. This observation has interesting implications in the interpretation of hormone concentrations in condi- tions of inborn deficiency of a BP. For example, in Laron dwarfism, there is virtual absence of the GH-BP in plasma, while serum GH concentrations are very high $(12,13,37,38)$. This increase in mean serum $\mathrm{GH}$ concentrations indicates mathematically that either the secretion rate and / or the $t_{1 / 2}$ of GH are increased (or the $V_{0}$ for $\mathrm{GH}$ is decreased) in Laron dwarfs. Available data suggest that increased secretion rather than a prolonged $t_{1 / 2}$ of $\mathrm{GH}$ occurs in this clinical model of $\mathrm{GH}$ receptor/BP deficiency (39), in that the predicted (see Fig. 3) and measured half-lives of $\mathrm{GH}$ are actually decreased in the absence of BP (17-19, and Z. Laron, M. L. Johnson, and J. D. Veldhuis, unpublished data). Such an increase in GH secretion rate presumably results from the failure of GH-dependent negative feedback mechanisms (such as generation of insulin-like growth factor I, or IGF-I) to suppress GH secretion (40). Of note, Laron-type dwarfism is not simply a GH-BP deficiency state. The fact that $\mathrm{GH}$ receptors are also absent $(38,41)$ is likely to influence free and total $\mathrm{GH} t_{1 / 2}$ independently of the $\mathrm{BP}$, as at least part of the clearance of $\mathrm{GH}$ proceeds through receptor-mediated internalization into cells and lysosomal degradation. Thus, the combined absence of plasma GH-BP 

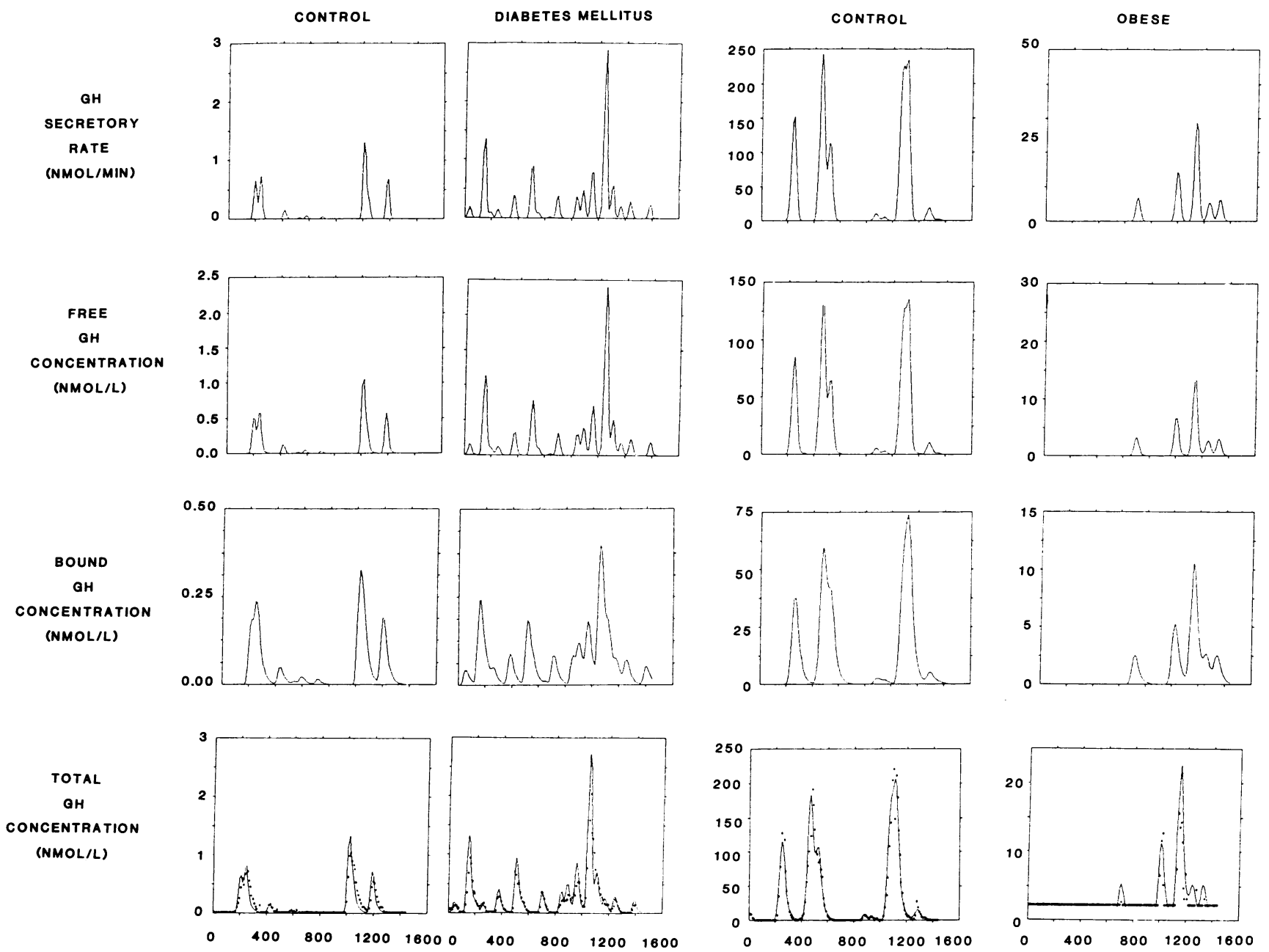

TIME (MIN)

TIME (MIN)

Figure 7. Dynamic features of GH secretion into free and bound compartments and the resultant effects on total serum GH concentrations (left panels) in a healthy young male (control) and a man with type 1 diabetes mellitus with reduced plasma GH-binding protein concentrations, or (right panels) a middle-aged male control and obese counterpart. Each subject underwent blood sampling at 10 -min intervals for $24 \mathrm{~h}$, and the resultant sera were subjected to immunoradiometric assay to estimate total serum GH concentrations (lowermost panels). The GH secretory rate over time was then determined by multiparameter deconvolution analysis (33) (uppermost panels). The free and bound serum GH concentrations were defined by conservation of mass, estimated GH-binding protein capacities of respectively $1.0,0.725$, and $1.7 \mathrm{nM}$ in the control, diabetic, and obese individuals, a GH distribution volume of 4.9 liters, and an equilibrium $K_{\mathrm{d}}$ of $1.5 \mathrm{mM}$. Nonlinear curve-fitting of the observed total serum GH concentrations was carried out to estimate the half-life of free $\mathrm{GH}$, which was $\sim 3.25$ min in the young normal and diabetic men compared to 2.0 and $1.75 \mathrm{~min}$ in the middle-aged normal and obese men. (These individual values fall within the broad normal range of 2-12 min predicted in Fig. 3.) The total GH half-life was $24 \mathrm{~min}$ in the normal young subject and 16 minutes in the diabetic man, which compares with 14 and $10 \mathrm{~min}$ in the nonobese and obese middle-aged volunteers. Note that the numbers of detectable GH secretory episodes were 9 and 17, respectively (control vs. diabetes mellitus), with corresponding GH interburst intervals of 123 and 84 min, and daily GH secretion rates of 0.573 vs. $1.42 \mathrm{mg}$. Similar deconvolution estimates of episodic GH secretion were obtained in six other control and diabetic individuals. In the obese and normal weight middle-aged men, there were, respectively, 5 and 9 detectable GH secretory bursts per $24 \mathrm{~h}$ (interburst intervals of 156 and $137 \mathrm{~min}$ ), and daily $\mathrm{GH}$ secretion rates of 0.013 and $0.22 \mathrm{mg}$. The continuous curves drawn through the total serum GH concentrations are predicted values, which agree well with the observed measurements (also shown).

(which normally prolongs $t_{1 / 2}$ ) and tissue GH receptors (which normally shorten $t_{1 / 2}$ ) may have unpredictable net effects on GH clearance in that condition (42-45).

The GH-BP complex is known to exert complex biological effects on target tissues. For example, addition of unoccupied BP in vitro impairs $\mathrm{GH}$ action $(44,45)$, yet in vivo the $B P$ can enhance $\mathrm{GH}$ action in a dose-dependent fashion $(46,47)$. This seeming paradox is most likely explained by the opposing effects of competition for ligand on the one hand (42-44) and prolongation of $t_{1 / 2}$ on the other (17-19). Hence, subject to the assumption that unoccupied BP has no intrinsic effects itself (44), regulation of the amount of unoccupied BP in plasma or in tissues can provide a plausible mechanism for modulating the plasma retention time and local tissue actions of $\mathrm{GH}$. Our 


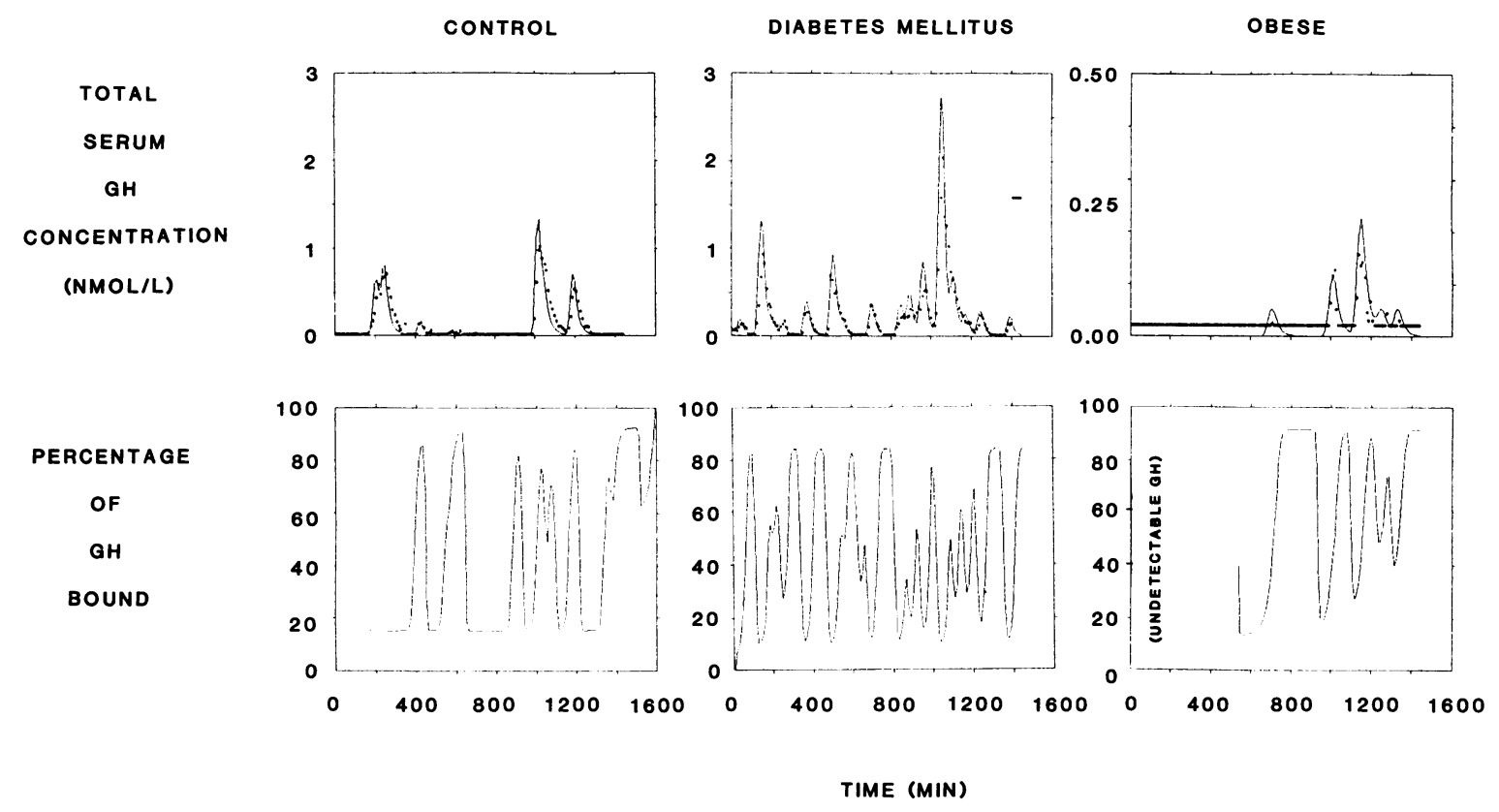

Figure 8. Total serum GH concentrations and percentage GH bound to GH-BP in a healthy (control), an insulin-dependent diabetic patient, and an obese man, all of whom underwent blood sampling as described in the legend to Fig. 7. (Upper panels) The predicted curves for measured total serum GH concentrations are reproduced from Fig. 7. (Lower panels) The percentage of GH bound to its high-affinity plasma BP is depicted. Note that the percentage of GH bound to the transport protein is not in steady state but varies from $~ 10 \%$ to $80 \%$ over 24 hs. Occasional high "plateau" regions of the plot of percentage GH bound over time denote indeterminate estimates, in that serum GH concentrations at these times fell below the limit of detection of the particular GH IRMA $(0.5 \mathrm{ng} / \mathrm{ml},=0.0225 \mathrm{nM})$. This also occurred at the outset of sampling in the obese subject.

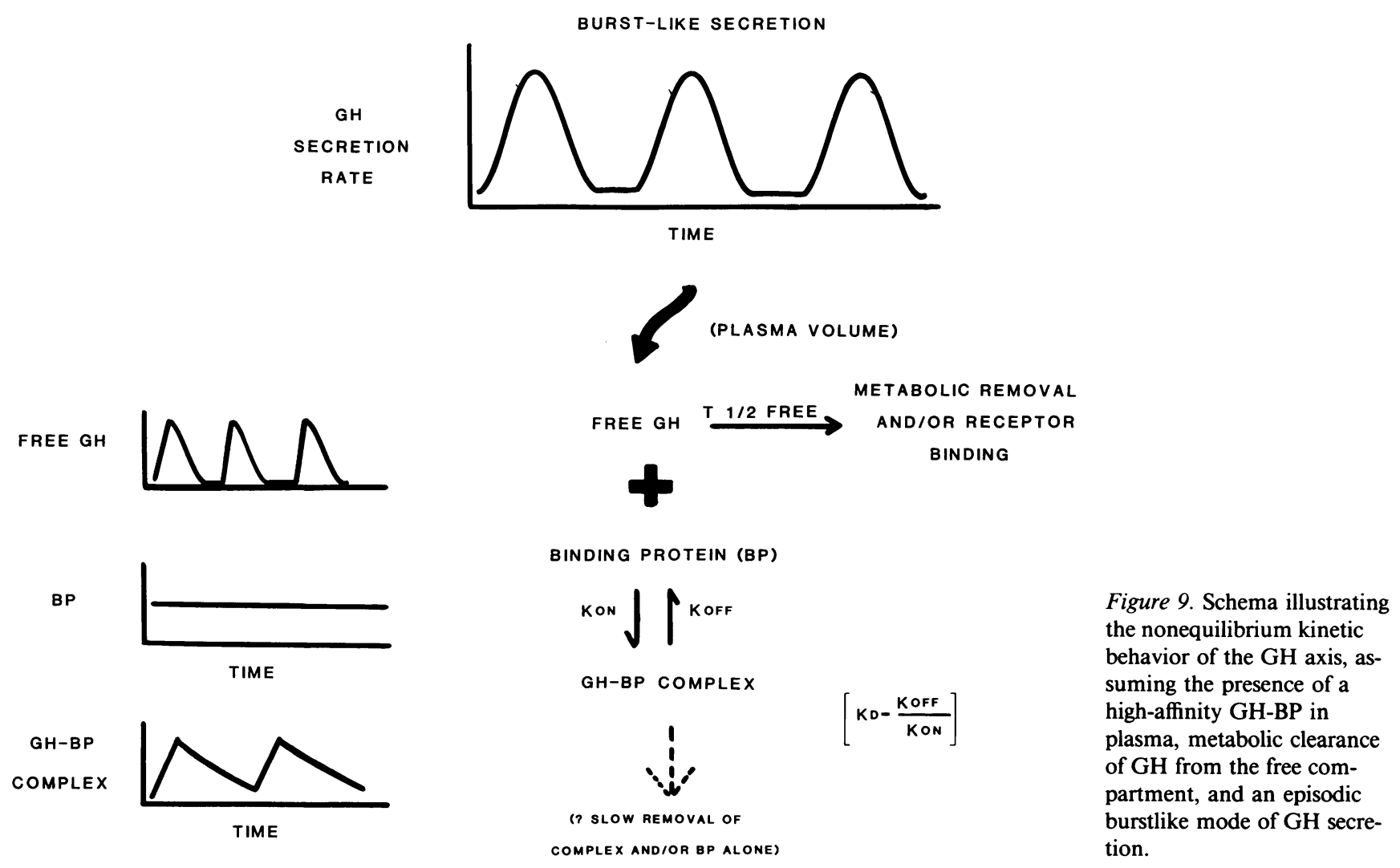


computer simulations indicate that ceteras paribus the amount of unoccupied BP is controlled by the $V_{0}$ and the secretion rate of $\mathrm{GH}$ (at high secretion rates, there is a reduced amount of unoccupied BP), as well as the free GH half-life (if $t_{1 / 2}$ is prolonged, fewer binding sites on BP will remain unoccupied). Similarly, the affinity of the BP regulates the availability of unoccupied binding sites.

Clinical correlations indicate that the $\mathrm{GH}$ secretion rate is inversely related to the level of GH-BP in plasma in healthy boys (46). Thus, children with low BP levels tend to have high GH secretion rates, and vice versa. Our computer simulations predict that this physiological relationship in a group of subjects would tend to damp pulsatile free $\mathrm{GH}$ availability to target tissues. A buffering effect of constant amounts of high-affinity GH-BP also occurs in individuals over minutes and hours, as shown in Fig. 8 in a normal, diabetic, and obese subjects. In all three conditions, the percentage of $\mathrm{GH}$ bound to high-affinity GH-BP varies remarkably over $24 \mathrm{~h}$; viz., from $10 \%$ to $80 \%$ during the course of minute-to-minute pulsatile $\mathrm{GH}$ release (Fig. 8). Of particular interest, the relative retention of $\mathrm{GH}$ in plasma by GH's complexing with BP prevents plasma GH concentrations from falling to zero between successive GH secretory bursts. Indeed, the dissociation rate constant of 0.037 / min equates to a half-life of $\mathrm{GH}$ dissociation of $18.7 \mathrm{~min}$, which is considerably longer than our estimated free $\mathrm{GH}$ halflife of $\sim 7(2-12) \mathrm{min}$. Thus, the percentage of GH bound to BP will tend to rise following a secretory burst, as free $\mathrm{GH}$ is removed more rapidly than bound. Dissociation of $\mathrm{GH}$ from its BP at these times of low or absent GH secretion maintains some free $\mathrm{GH}$ in plasma bathing the target tissues, which in circumstances of decreased GH secretion (obesity) may be physiologically relevant. However, whether such low but nonzero concentrations of free GH or GH-BP complex are important in maintaining tissues responsiveness to GH is not known.

Assuming that free hormone is the major (but not necessarily exclusive) moiety subject to irreversible metabolic removal, then differences in the $t_{1 / 2}$ of free hormone among different individuals will influence the absolute amounts of free and bound GH in plasma, and the percentage occupancy of the GH-BP. Up to fourfold variability has been recognized in the $t_{1 / 2}$ of exogenously infused $\mathrm{GH}$, and more recently of endogenously secreted GH in healthy individuals (reviewed in references 29 and 33). Based on Fig. 3, we therefore can predict free GH half-lives of 2-12 min in normal adults. Thus, whether free and/or bound $\mathrm{GH}$ acts on target tissues, this variability in $\mathrm{GH} t_{1 / 2}$ has the potential to modify tissue actions of $\mathrm{GH}$ significantly.

In obese men, the calculated $t_{1 / 2}$ of endogenous GH appears to be somewhat reduced (31). Such calculations assume that the $V_{0}$ for $\mathrm{GH}$ is not significantly increased in obesity. Similarly, in obese orchidectomized Rhesus monkeys, the metabolic clearance rate of human $\mathrm{GH}$ infused at a constant rate is significantly higher (47). A decrease in $\mathrm{GH} t_{1 / 2}$ (or increase in metabolic clearance rate) would decrease the amount of free and bound $\mathrm{GH}$ bathing target tissues, and thereby contribute to tissue $\mathrm{GH}$ deficiency in obesity. Decreased $\mathrm{GH} t_{1 / 2}$ is not due to evident alterations in BP affinity or capacity, since the estimated serum GH binding capacity is either high-normal or moderately increased in obese men $(31,48)$. Thus, alternative mechanisms for the decrease in apparent $\mathrm{GH} t_{1 / 2}$ in obese individuals should be considered, and might include increased re- moval of GH by receptor and/or nonreceptor-mediated mechanisms and/or an increased $V_{0}$ for GH.

Our measurements of GH-BP concentrations in type I (insulin-dependent) diabetes mellitus reveal a significantly reduced GH-BP capacity (49). In conjunction with increased GH secretion in type I diabetic patients, the decrease in GH-BP capacity amplifies the already high free $\mathrm{GH}$ concentration in plasma and would tend to shorten the half-life of total GH (see Fig. 7, left panels). These observations are consistent with the free $\mathrm{GH}$ hypothesis, i.e., metabolic removal of $\mathrm{GH}$ proceeds largely or predominantly via free $\mathrm{GH}$ rather than by way of complexes of GH-BP.

Our computer simulations also provide a possible basis for interpreting some apparent differences in the reported $\mathrm{GH} t_{1 / 2}$ in the literature. For example, estimating $\mathrm{GH} t_{1 / 2}$ before steady state is attained or in response to infusions of pharmacological amounts of GH sufficient to exceed BP capacity would produce a preferential increase in free hormone and yield initial phase kinetic estimates reflecting predominantly the short $t_{1 / 2}$ of free hormone. However, measurements of the $\mathrm{GH} t_{1 / 2}$ within the physiological GH concentration range of $50 \mathrm{ng} /$ liter to $50 \mu \mathrm{g} / \mathrm{L}(\sim 2.3 \mathrm{pM}$ to $2.3 \mathrm{nM})$ would reflect free $\mathrm{GH} t_{1 / 2}$ only if the laboratory technique did not measure bound hormone-an unlikely possibility in the case of immunoassays (25). Indeed standard immunochemical assays typically measure total GH in plasma (25). Thus, the half-lives derived from such measurements reflect the damping effect of the GH-BPs, the concentration of which varies among individuals $(11,14)$. The variability in BP levels may in part explain individual differences in GH clearance. Of course, other factors can introduce variability in estimates of $\mathrm{GH} t_{1 / 2}$, including measurement technique, assay specificity, buffer and matrix, choice of GH standards, sampling frequency, and the extent to which endogenous GH secretion is suppressed when the $t_{1 / 2}$ of exogenous $\mathrm{GH}$ is computed.

The dynamic model of $\mathrm{GH}$ secretion and $\mathrm{GH}$ partitioning between BP and metabolic clearance presented here can be used to predict the time course of plasma GH-BP complex and free GH. Although the time course of total, free, and bound $\mathrm{GH}$ in blood can be predicted, the exact temporal profiles of free and bound $\mathrm{GH}$ to which tissue $\mathrm{GH}$ receptors are exposed are not known, since the relative extent to which free $\mathrm{GH}$ and GH-BP complex permeate various target tissues has not been defined. An additional unanswered question is: "What timeconfiguration of free GH (or GH-BP complex) in blood most effectively initiates or modifies tissue responses to GH?" For example, under some conditions, a pulsatile rather than a continuous mode of GH delivery preferentially enhances tissue responses, such as linear growth and weight gain in the rat and the induction of epiphyseal cartilage and muscle IGF-I mRNA (50). In contrast, in acromegaly, the nadir (or mean or integrated) serum $\mathrm{GH}$ concentration is the strongest single correlate of serum IGF-I concentrations (36). Moreover, the induction of a "feminized" pattern of certain hepatic enzymes (e.g., carbonic anhydrase in the rat) is best achieved by continuous GH delivery ( 51 ). Near-continuous $\mathrm{GH}$ replacement may also be optimal for generating IGF-I in GH-deficient humans (52).

In conclusion, assuming that plasma GH concentration profiles are transferred to tissue receptor sites, the dynamic interplay among pulsatile GH secretion, intravascular GH partitioning, distribution, high-affinity binding, and irreversible 
metabolic clearance offers significant regulatory control over tissue GH actions within the somatotropic axis in health and disease.

\section{Acknowledgments}

We thank Patsy Craig for her skillful preparation of the manuscript, Drs. W. S. Evans and C. M. Asplin for providing the 24-h serum GH profiles in type I diabetes mellitus, and Paula P. Azimi for the artwork.

This work was supported in part by National Institutes of Health grant RR 00847 to the Clinical Research Center of the University of Virginia, RCDA 1 KO4 HD00634 (to Dr. Veldhuis), GM-28928 (to Dr. Johnson), DK-38128 (to Dr. Baumann), the Diabetes and Endocrinology Research Center grant NIH DK-38942, the National Institutes-supported Clinfo Data Reduction Systems, the Pratt Foundation, the University of Virginia Academic Enhancement Fund, the National Science Foundation Science Center for Biological Timing, and the Northwestern Memorial Foundation.

\section{References}

1. Baumann, G., M. W. Stolar, K. Amburn, C. P. Barsano, and B. C. De Vries. 1986. A specific growth hormone-binding protein in human plasma: initial characterization. J. Clin. Endocrinol. Metab. 62:134-141.

2. Herington, A. C., S. Ymer, and J. Stevenson. 1986. Identification and characterisation of specific binding proteins for growth hormone in normal human sera. J. Clin. Invest. 77:1817-1823.

3. Ymer, S. I., and A. C. Herington. 1985. Evidence for the specific binding of growth hormone to a receptor-like protein in rabbit serum. Mol. Cell. Endocrinol. 41:153-161.

4. Spencer, S. A., R. G. Hammonds, and W. J. Henze, H. Rodriquez, M. J. Waters, and W. I. Wood. 1988. Rabbit liver growth hormone receptor and serum binding protein: purification, characterization and sequence. J. Biol. Chem 263:7862-7867.

5. Leung, D. W., S. A. Spencer, G. Cachianes, R. G. Hammonds, C. Collins, W. J. Henzel, R. Barnard, M. J. Waters, and W. I. Wood. 1987. Growth hormone receptor and serum binding protein: purification, cloning, and expression. Nature (Lond.). 330:537-543.

6. Smith, W. C., J. Kuniyoshi, and F. Talamantes. 1989. Mouse serum growth hormone $(\mathrm{GH})$ binding protein has $\mathrm{GH}$ receptor extracellular and substituted transmembrane domains. Mol. Endocrinol. 3:984-990.

7. Baumbach, W. R., D. L. Horner, and J. S. Logan. 1989. The growth hormone-binding protein in rat serum is an alternatively spliced form of the rat growth hormone receptor. Genes Dev. 3:1199-1205.

8. Baumann, G., and M. A. Shaw. 1988. Immunochemical similarity of the human plasma growth hormone-binding protein and the rabbit liver growth hormone receptor. Biochem. Biophys. Res. Commun. 152:573-578.

9. Barnard, R., P. Quirk, and M. J. Waters. 1989. Characterization of the growth hormone-binding protein of human serum using a panel of monoclonal antibodies. J. Endocrinol. 123:327-332.

10. Baumann, G., and M. A. Shaw. 1990. A second, lower affinity growth hormone-binding protein in human plasma. J. Clin. Endocrinol. Metab. 70:680686.

11. Baumann, G., M. A. Shaw, and K. Amburn. 1989. Regulation of plasma growth hormone-binding proteins in health and disease. Metab. Clin. Exp. 38:683-689.

12. Daughaday, W. H., and B. Trivedi. 1987. Absence of serum binding protein in patients with growth hormone receptor deficiency (Laron dwarfism) Proc. Natl. Acad. Sci. USA. 84:4636-4640.

13. Baumann, G., M. A. Shaw, and R. J. Winter. 1987. Absence of the plasma growth hormone-binding protein in Laron-type dwarfism. J. Clin. Endocrinol. Metab. 65:814-816.

14. Daughaday, W. H., B. Trivedi, and B. A. Andrews. 1987. The ontogeny of serum GH binding protein in man: a possible indicator of hepatic $\mathrm{GH}$ receptor development. J. Clin. Endocrinol. Metab. 65:1072-1074.

15. Baumann, G., M. A. Shaw, and T. J. Merimee. 1989. Low levels of highaffinity growth hormone-binding protein in African pygmies. N. Engl. J. Med. 320:1705-1709.

16. Baumann, G., M. A. Shaw, R. C. Brumbaugh, and J. Schwartz. 1991. Short stature and decreased growth hormone-binding protein in the Mountain Ok People of Papua New Guinea. J. Clin. Endocrinol. Metab. 72:1346-1349.

17. Baumann, G., M. W. Stolar, and T. A. Buchanan. 1987. The effect of circulating growth hormone binding protein on metabolic clearance, distribution and degradation of human growth hormone. J. Clin. Endocrinol. Metab. 64:657660 .

18. Baumann, G., M. A. Shaw, and T. A. Buchanan. 1989. In vivo kinetics of a covalent growth hormone-binding protein complex. Metab. Clin. Exp. 38:330333.

19. Moore, J., R. Vandlen, P. MacKay, and S. A. Spencer. 1988. Serum clearance of human growth hormone bound to growth hormone binding protein. Endocrinology. 122(Suppl.):121. (Abstr.)

20. Barsano, C. P., and G. Baumann. 1989. Simple algebraic and graphic methods for the apportionment of hormone (and receptor) into bound and free fractions in binding equilibria; or how to calculate bound and free hormone? Endocrinology. 124:1101-1106.

21. Veldhuis, J. D., and M. L. Johnson. 1992. Computer-assisted algorithms to analyze pulsatile growth hormone release. Excerpta Med. Int. Congr. Ser. In press.

22. Baumann, G., K. Amburn, and M. A. Shaw. 1988. The circulating growth hormone (GH)-binding protein complex: a major constituent of plasma GH in man. Endocrinology. 122:976-984.

23. Baumann, G., J. G. MacCart, and K. Amburn. 1983. The molecular nature of circulating growth hormone in normal and acromegalic man: evidence for a principal and minor monomeric forms. J. Clin. Endocrinol. Metab. 56:946952.

24. Baumann, G. 1991. Growth hormone heterogeneity: genes, isohormones, variants and binding proteins. Endocrine Rev. 12:424-449.

25. Jan, T., M. A. Shaw, and G. Baumann. 1990. Effects of growth hormonebinding proteins on serum growth hormone measurements. J. Clin. Endocrinol. Metab. 72:387-391.

26. Snow, K. J., M. A. Shaw, L. M. Winer, and G. Baumann. 1990. Diurnal pattern of growth hormone binding protein in man. J. Clin. Endocrinol. Metab. 70:417-420.

27. Carlsson, L., S. Rosberg, W. L. Wong, and K. Albertsson-Wikland. 1991. Analyses of 24-hour plasma profiles of growth hormone $(\mathrm{GH})$ binding protein in healthy children. Horm. Res. 35:63. (Abstr.)

28. Owens, D., M. C. Srivastava, C. V. Tompkins, J. D. N. Nabarro, and P. H. Sonksen. 1973. Studies on the metabolic clearance rate, apparent distribution space and plasma half-disappearance time of unlabelled human growth hormone in normal subjects and in patients with liver disease, renal disease, thyroid disease and diabetes mellitus. Eur. J. Clin. Invest. 3:284-294.

29. Faria, A. C. S., J. D. Veldhuis, M. O. Thorner, and M. L. Vance. 1989. Half-time of endogenous growth hormone $(\mathrm{GH})$ disappearance in normal man after stimulation of $\mathrm{GH}$ secretion by GH-releasing hormone and suppression with somatostatin. J. Clin. Endocrinol. Metab. 68:535-541.

30. Iranmanesh, A., G. Lizarralde, and J. D. Veldhuis. 1991. Age and relative adiposity are specific negative determinants of the frequency and amplitude of GH secretory bursts and the half-life of endogenous GH in healthy men. J. Clin. Endocrinol. Metab. 73:1081-1088.

31. Veldhuis, J. D., A. Iranmanesh, K. K. Y. Ho, G. Lizarralde, M. J. Waters, and M. L. Johnson. 1991. Dual defects in pulsatile growth hormone secretion and clearance subserve the hyposomatotropism of obesity in man. J. Clin. Endocrinol. Metab. 72:51-59.

32. Ulloa-Aguirre, A., R. M. Blizzard, E. Garcia-Rubi, A. D. Rogol, K. Link, C. M. Christie, M. L. Johnson, and J. D. Veldhuis. 1990. Testosterone and oxandrolone, a non-aromatizable androgen, specifically amplify the mass and rate of growth hormone $(\mathrm{GH})$ secreted per burst without altering $\mathrm{GH}$ secretory burst duration of frequency or the GH half-life. J. Clin. Endocrinol. Metab. 71:846854.

33. Hartman, M. L., A. C. S. Faria, M. L. Vance, M. L. Johnson, M. O. Thorner, and J. D. Veldhuis. 1991. Temporal structure of in vivo growth hormone secretory events in man. Am. J. Physiol. 260:E101-E110.

34. Shampine, L. F., H. A. Watts, and S. M. Davenport. 1976. Solving nonstiff ordinary differential equations-the state of the art. SIAM Rev. 18:376-441.

35. Winer, L. M., M. A. Shaw, and G. Baumann. 1990. Basal plasma growth hormone levels in man: new evidence for rhythmicity of growth hormone secretion. J. Clin. Endocrinol. Metab. 70:1678-1686.

36. Hartman, M. L., J. D. Veldhuis, M. L. Vance, A. C. S. Faria, R. W. Furlanetto, and M. O. Thorner. 1990. Somatotropin pulse frequency and basal growth hormone concentrations are increased in acromegaly. J. Clin. Endocrinol. Metab. 70:1375-1384.

37. Silbergeld, A., I. Lazar, B. Erster, R. Keret, R. Tepper, and Z. Laron. 1989. Serum growth hormone binding protein activity in healthy neonates, children and young adults: correlation with age, height and weight. Clin. Endocrinol. 31:295-303.

38. Eshet, R., Z. Laron, A. Pertzelan, R. Arnon, and M. Dintzman. 1984. Defect of human growth hormone receptors in the liver of two patients with Laron-type dwarfism. Isr. J. Med. Sci. 20:8-11.

39. Keret, R., A. Pertzelan, A. Zeharia, Z. Zadik, and Z. Laron. 1988. Growth hormone (hGH) secretion and turnover in three patients with Laron-type dwarfism. Isr. J. Med. Sci. 24:75-79.

40. Berelowitz, M., M. Szabo, L. A. Frohman, S. Firestone, and L. Chu. 1981. 
Somatomedin- $\mathrm{C}$ mediates growth hormone negative feedback by effects on both the hypothalamus and the pituitary. Science (Wash. DC). 212:1279-1281.

41. Godowski, P. J., D. W. Leung, L. R. Meacham, J. P. Galgani, R. Hellmiss, R. Keret, P. S. Rotwein, J. S. Parks, Z. Laron, and W. I. Wood. 1989. Characterization of the human growth hormone receptor gene and demonstration of a partial gene deletion in two patients with Laron-type dwarfism. Proc. Natl. Acad. Sci. USA. 86:8083-8087.

42. Lim, L., S. A. Spencer, P. McKay, and M. J. Waters. 1990. Regulation of growth hormone $(\mathrm{GH})$ bioactivity by a recombinant human GH-binding protein. Endocrinology. 127:1287-1291.

43. Mannor, D. A., L. M. Winer, M. A. Shaw, and G. Baumann. 1991. Plasma growth hormone binding proteins: effect on growth hormone binding to receptors and on growth hormone action. J. Clin. Endocrinol. Metab. 73:30-34.

44. Mannor, D. A., M. A. Shaw, L. M. Winer, and G. Baumann. 1988 Circulating growth hormone-binding proteins inhibit growth hormone (GH) binding to GH receptors but not in vivo GH action. Clin. Res. 36:870a. (Abstr.)

45. Clark, R. G., B. Cunningham, J. A. Moore, M. G. Mulkerrin, L. M. S. Carlsson, S. A. Spencer, W. I. Wood, and M. J. Cronin. 1991. Growth hormone binding protein enhances the growth promoting activity of GH in the rat. In 199 Program, 73rd Meeting of the Endocrine Society. 1611. (Abstr.)

46. Martha, Jr., P. M., A. D. Rogol, R. M. Blizzard, M. A. Shaw, and G. Baumann. 1991. Growth hormone-binding protein activity is inversely related to 24 hour growth hormone release in normal boys. J. Clin. Endocrinol. Metab. 73:175-181.

47. Dubdey, A. K., A. Ahanukoglu, B. C. Hansen, and A. A. Kowarski. 1988
Metabolic clearance rates of synthetic human growth hormone in lean and obese male rhesus monkeys. J. Clin. Endocrinol. Metab. 67:1064-1067.

48. Hochberg, Z., P. Hertz, V. Colin, S. Ish-Shalom, D. Yeshurun, M. B. Youdim, and T. Amit. 1992. The distal axis of growth hormone (GH) in nutritional disorders: GH-binding protein, insulin-like growth factor-I (IGF-I), and IGF-I receptors in obsesity and anorexia nervosa. Metab. Clin. Exp. 41:106-112.

49. Mercado, M., M. E. Molitch, and G. Bauman. 1992. Low plasma growth hormone binding protein in insulin-dependent diabetes mellitus. Diabetes. 41:605-609.

50. Isgaard, J., L. Carlsson, O. G. P. Isaksson, and J. O. Jansson. 1988. Pulsatile intravenous growth hormone (GH) infusion in hypophysectomized rats increases insulin-like growth factor I messenger RNA in skeletal tissues more effectively than continuous GH infusion. Endocrinology. 123:2605-2610.

51. Jeffrey, S., N. D. Carter, R. G. Clark, and I. C. Robinson. 1990. The episodic secretory pattern of growth hormone regulates liver carbonic anhydrase. III. Studies in normal and mutant growth hormone-deficient dwarf rats. Biochem. J. 266:69-74.

52. Jorgensen, J. O. L., N. Moller, T. Lauritzen, and J. S. Christiansen. 1990. Pulsatile versus continuous intravenous administration of growth hormone (GH) in GH-deficient patients: effects on circulating IGF-I and metabolic indices. J. Clin. Endocrinol. Metab. 70:1616-1623.

53. Cunningham, B. C. M. Ultsch, A. M. DeVos, M. G. Mulkerrin, K. R. Clauser, and J. A. Wells. 1991. Dimerization of the extracellular domain of the human growth hormone receptor by a single hormone molecule. Science (Wash. DC). 254:821-825. 